\title{
SEKOLAH UNGGULAN TUNTUTAN PENDIDIKAN GLOBAL
}

\author{
Syuhud \\ syuhudlu@gmail.com \\ Institut Agama Islam Syarifuddin Lumajang, Indonesia
}

\begin{abstract}
ABSTRAK
Perkembangan dunia pendidikan sangat pesat dan kompetitif, dunia global banyak memberikan kontribusi arah perubahan dunia pendidikan, temasuk di Indonesia. Perubahan ini menuntut pada setiap lembaga pendidikan untuk terus berpacu dengan waktu dalam perubahan dan persaingan yang dinamis, lembaga pendidikan yang mampu menunjukkan keunggulannya yang akan bisa masuk dalam persaingan ini. Sekolah unggulana yang menjadi impian semua kalangan dan golongan seharusnya sudah jelas terminologinya yang dapat dipahami oleh semua orang, sehingga kata "unggul" ini tidak menjadi superioritas intelektual sebagian orang. Di beberapa negara-negara maju, untuk menunjukkan sekolah yang baik tidak menggunakan kata unggul (excellent) tetapi menggunakan istilah efektif dan lain sebagainya, dari sisi ukuran muatan sekolah unggulan di Indonesia juga tidak memenuhi syarat. Sekolah unggulan di Indonesia hanya mengukur sebagian kemampuan akademis. Dalam konsep yang sesungguhnya sekolah unggul adalah sekolah yang secara terus menerus meningkatkan kinerjanya dan menggunakan sumber daya yang dimilikinya secara optimal untuk menumbuhkembangkan prestasi siswa secara menyeluruh.
\end{abstract}

Kata Kunci : Sekolah Unggul, Kinerja, Pendidikan Global 


\section{Pendahuluan}

Era global yang penuh dengan perubahan-perubahan di segala bidang, era kecepatan informasi yang dapat dengan mudah diakses dari berbagai media, cetak dan elektronik terutama internet. Sebenarnya keadaan ini telah melampaui suatu perubahan yang signifikan sepanjang sejarah ummat manusia, hanya dalam jangka 100-200 tahun, perubahan telah berlangsung dengan cepat dari abad pertanian (Agricultire age) menuju abad industri (Industry age) dan sekarang telah menuju abad baru yaitu abad informasi (Information age). Abad yang meminta manusia selalu inovatif, kreatif dan peka terhadap perkembangan zaman.

Perubahan yang disebabkan oleh globalisasi ini pada akhirnya membentuk karakteristik masyarakat abad XXI yang penuh dengan informasi yang masuk secara global, yang ditandai oleh masyarakat kompetitif sehingga tidak ada tempat dalam masyarakat tanpa kompetisi, kompetisi global. Kompetisi pada abad ke-21 ini merupakan prinsip dan kenyataan hidup yang baru, karena dunia terbuka dan bersaing untuk mendapatkan sesuatu yang lebih baik. Mereka sering bersemboyan "Hari esok harus lebih baik dari hari kemarin". Abad ini selalu menuntut manusia untuk dapat bersaing dengan kemajuan yang ada baik dari segi pemikiran maupun yang lainnya. ${ }^{1}$ Sebagai lembaga yang bertanggung jawab dalam menyiapkan kader-kader bangsa, maka lembaga pendidikan harus selalu berusaha dan berinovasi bagaimana cara menyiapkan generasi bangsa tersebut menghadapi tantangan zaman yang dihadapi.

Paling tidak ada dua faktor pokok yang menyebabkan kompetisi dalam dunia pendidikan, Pertama, semakin tingginya tingkat kehidupan

\footnotetext{
1 H.A.R Tilaar, Beberapa agenda Reformasi Pendidikan Nasional dalam Persepektif Abad 21, (Jakarta:Indonesia Tera, 1999) , 135
} 
sosial masyarakat seiring dengan perkembangan Iptek, semakin meningkatkan tuntutan masyarakat terhadap lembaga pendidikan (sekolah). Karena itu sekolah diyakini mampu menjawab dan mengantisipasi berbagai tantangan masa depan, tuntutan yang dimaksud disini adalah tuntutan terhadap kualitas pendidikan. Kedua, perubahan kebijakan politik sentralisasi (Top down) menjadi (Bottom Up). Dengan penerapan desentralisasi ini wewenang dalam menentukan kebijakan atau keputusan yang semula berasal dari pusat maka kemudian sepenuhnya diserahkan kepada sekolah atau lembaga pendidikan dimaksud (Otonomi pendidikan)2 ${ }^{2}$ Sehingga sekolah dituntut untuk mandiri dan mampu mengembangkan sekolahnya sesuai dengan tuntutan dan kebutuhan zaman..

\section{Konsep Sekolah Unggulan}

Sebenarnya sebutan sekolah unggulan itu kurang tepat, kata "unggul" menyiratkan adanya superioritas dibanding dengan yang lain. Kata ini menunjukkan adanya " kesombongan " intelektual yang sengaja ditanamkan di lingkungan sekolah. Di negara-negara maju, untuk menunjukkan sekolah yang baik tidak menggunakan kata unggul (excellent) melainkan effectif, develop, accelerate, essential. ${ }^{3}$ Dari sisi ukuran muatan keunggulan, sekolah unggulan di Indonesia juga tidak memenuhi syarat. Sekolah unggulan di Indonesia hanya mengukur sebagian kemampuan akademis. Dalam konsep yang sesungguhnya sekolah unggul adalah sekolah yang secara terus menerus meningkatkan kinerjanya dan menggunakan seumber daya yang dimilikinya secara optimal untuk menumbuhkembangkan prestasi siswa secara menyeluruh.

\footnotetext{
2 Nanang Fatah, Manajemen Berbasis Sekolah, (Bandung: Andira, 2000),

3 Susan Alberts Mohrman, dkk. School Based Management : Organizing for Hight

Performance, (San Fransisco: Jossey-Bass, 1994), 81
} 
Berarti bukan hanya prestasi akademis saja yang ditumbuhkembangkan, melainkan potensi psikis, fisik, etik, moral, religi, emosi, spirit, adversity dan intelegensi.

Sekolah Unggulan dapat didefenisikan sebagai sekolah yang dikembangkan untuk mencapai keunggulan yang dihasilkan (Out put/Outcome) dari pendidikan yang dilaksanakan. Artinya sekolah unggul itu dikembangkan dan diproses sebagaimana sekolah-sekolah konvensional lain yang telah berkembang selama ini dengan memberikan tambahan perlakuan yang lebih kepada semua peserta didik. ${ }^{4}$ Sekolah unggulan yang sebenarnya dibangun secara bersamasama oleh seluruh warga sekolah (stake holder) bukan hanya oleh pemegang otoritas pendidikan. Dalam konsep sekolah unggulan yang saat ini diterapkan untuk menciptakan prestasi siwa yang tinggi, maka harus dirancang kurikulum yang baik yang diajarkan oleh guru yang berkualitas tinggi. Padahal sekolah unggulan yang sebenarnya keunggulan akan dapat dicapai apabila seluruh seumber daya sekolah dimanfaatkan secara optimal. Berarti tenaga administrai, pengembang kurikulum di sekolah, kepala sekolah, dan penjaga sekolah pun harus dilibatkan secara aktif. Karena semua sumber daya tersebut akan menciptakan iklim sekolah yang mampu membentuk keunggulan sekolah.

Keunggulan sekolah terletak pada bagaimana cara sekolah merancang bangun sekolah sebagai organisasi. Maksudnya adalah bagaimana struktur organisasi pada sekolah itu di susun, bagaimana warga sekolah berpartisipasi, bagaimana setiap orang memiliki peran dan tanggung jawab yang sesuai dan bagaimana terjadinya pelimpahan

\footnotetext{
${ }^{4}$ Tim Penyusun, Sistem Penyelenggaraan sekolah Unggul (Jakarta, Depdikbud RI, 1993), 5
} 
dan pendelegasian wewenang yang disertai tanggung jawab. Semua itu bermuara kepada kunci utama sekolah unggul adalah keunggulan dalam pelayanan kepada siswa dengan memberikan kesempatan untuk mengembangkan potensinya.

Sekolah unggul mencoba memberikan formula baru kepada peserta didik yang mempunyai potensi lebih agar dapat mengembangkan diri secara maksimal dan merasa selalu tertantang untuk terus mengembangkan kemampuannya sehingga nantinya diharapkan memiliki nilai plus dibandingkan dengan sekolah konvensional lain, baik dari segi kognitif, afektif dan psikomotoriknya. Untuk itu sekolah unggul menerapkan seleksi dalam penerapan input, menyediakan sarana dan prasarana yang menunjang, lingkungan yang kondusif, tenaga pendidik yang kompeten, kurikulum yang dipercaya dan lain sebagainya. Penyelenggaraan sekolah unggulan berorientasi kepada keunggulan sistemik yang dibangun dan dikembangkan sekolah. Dalam pengembangannya di sekolah, wawasan keunggulan harus menjiwai setiap komponen dari proses dalam pendidikan di sekolah. Wawasan keunggulan dapat ditumbuhkan melalui pengembangan aspek-aspek sebagai berikut, Pertama, keimanan dan ketaqwaan, kedua keahlian dan profesionalitas, ketiga, karya dan cipta, keempat, kemandirian dan kewiraswastaan, kelima, kekeluargaan dan kebersamaan. ${ }^{5}$

Keinginan untuk mencerdaskan kehidupan bangsa dalam mewujudkan tujuan pendidikan nasional yang bermuara pada tujuan pembangunan nasional memerlukan usaha yang sistematis, terarah, dan intens dalam menggali dan mengembangkan potensi manusia Indonesia secara optimal sehingga dapat menjadi bangsa yang maju sejahtera, damai

5 T. Cholik Mutohir, Wawasan Keunggulan dalam Konteks Pengembangan Sekolah Unggulan ( Surabaya:IKIP, 1997) 
dengan berdasarkan pancasila serta dihormati dan diperhitungkan oleh bangsa lain dalam percaturan global. Ini merupakan visi sekolah unggulan yang selalu ingin dicapai. Untuk misi yang dibawanya adalah meningkatkan dan mengembangkan potensi sumber daya manusia Indonesia sebagai subyek dan wahana untuk mencapai tujuan pembangunan nasional. Maka sasaran yang ingin dicapai oleh sekolah unggulan adalah menyiapkan para lulusan untuk memasuki jenjang pendidikan yang lebih tinggi, bermutu baik dalam negeri maupun luar negeri dan juga diproyeksikan untuk siap memasuki jalur kemandirian. ${ }^{6}$ Jadi sekolah unggulan itu penekanannya pada iklim belajar yang positif, di lingkungan sekolah. Sekolah unggul adalah sekolah yang mampu memproses (input) siswa bermutu rendah atau sedang menjadi lulusan yang bermutu tinggi (Out come atau out put tinggi). Dengan demikian, terdapat perbedaan yang mencolok pada prestasi akademik siswa, sebagai input rendah (bahkan lamban berfikir), tetapi outputnya tinggi. Berarti dalam sekolah tersebut terjadi proses belajar mengajar yang efektif, dan inilah yang sedang dikembangkan di sekolah-sekolah maju.

\section{Dasar Pemikiran Rekayasa Sekolah Unggulan.}

Lahirnya sebuah konsep sekolah unggul tentunya ada suatu dasar yang kuat dari pihak manajemen sekolah tersebut. Antara lain yang mendasari lahirnya sekolah unggul adalah dasar filosofis, sebagai berikut:

a. Manusia sebagai makhluk Tuhan telah dilengkapi berbagai kemampuan yang harus dikembangkan dan dimanfaatkan. Usaha untuk mewujudkan anugerah potensi tersebut secara penuh merupakan konsekuensi dari amanah Tuhan yang maha Esa.

\footnotetext{
${ }^{6}$ E. Mulyasa, Kurikulum Berbasis Kompetensi ( Bandung: Remaja Rosdakarya, 2003), 19-23
} 
b. Dalam pembangunan nasional manusia merupakan faktor sentral yaitu, sebagai subyek pembangunan. Pendidikan nasional mengemban tugas untuk membentuk manusia Indonesia menjadi manusia yang utuh dan merupakan sumber daya pembangunan.

c. Pendidikan nasional berusaha menciptakan keseimbangan antara pemerataan, pemberian kesempatan dan keadilan, berarti membuka seluas-luasnya kepada pesrta didik dari semua lapisan masyarakat untuk mendapatkan pendidikan tanpa dihambat oleh jenis kelamin, suku, bangsa dan agama.

Dari segi efektifitas penggunaan sumber daya, keberadaan sekolah unggulan ini mempunyai nilai strategis dalam memajukan keterlibatan dunia swasta untuk dapat berperan secara efektif dalam pembangunan pendidikan. Dengan adanya pengembangan ciri-ciri keunggulan tertentu yang sesuai dengan kekhasan potensi ekonomi, sosial dan budaya daerah setempat.Keberadaan sekolah unggulan memberikan kontribusi yang besar dalam perspektif pembangunan nasioanal.

\section{Kriteria Sekolah Unggulan}

Sebagaimana defenisi sekolah unggulan yang dijelaskan diatas, tujuan utama sekolah unggulan adalah untuk mencapai keunggulan dalam out put pendidikannya,maka sebagai tolok ukur keunggulan sebuah institusi pendidikan perlu dipaparkan dimensi-dimensi atau kriteria keunggulannya. Adapun dimensi-dimensi dimaksud adalah sebagai berikut :

a. Masukan (Input, Intake), berupa siswa yang di seleksi secara ketat dengan menggunakan kriteria tertentu dan prosedur yang dapat dipertanggungjawabkan, meliputi : 
1) Prestasi belajar siswa yang baik dengan indikator, angka raport, NEM, dan hasil tes akademik lainnya.

2) Skor psikotes yang meliputi intelegensi dan kreatifitas.

3) Tes fisik dan kesehatan

b. Sarana dan prasarana yang menunjang untuk memenuhi kebutuhan belajar siswa, serta dapat menyalurkan minat dan bakatnya baik dalam bidang intra kurikuler maupun ekstra kurikuler.

c. Lingkungan belajar yang kondusif, baik dari segi fisik maupun psikis.

d. Tenaga pendidik dan tenaga kependidikan mempunyai kualifikasi mutu yang baik sehingga sistem rekrutmennya diseleksi dengan ketat dan diberikan pembinaan dan pengetahuan intelektual.

e. Kurikulum yang diperkaya yaitu kurikulum yang dilakukan pengembangan dan improvisasi secara maksimal sesuai dengan tuntutan para peserta didik yang mempunyai keunggulan sehingga perlu adanya pengayaan dan percepatan pembelajaran .

f. Rentang waktu di sekolah lebih panjang sehingga perlu adanya sarana dan prasarana yang menunjang.

g. Proses belajar mengajar yang berkualitas, sehingga dapat dipertanggung jawabkan pada siswa, lembaga dan masyarakat.

h. Nilai lebih sekolah unggulan terletak pada perlakuan tambahan diluar kurikulum nasional melalui pengembangan materi kurikulum, program pengayaan dan perluasan serta pengajaran 
remedial,pelayanan bimbingan dan konseling,pembinaan kreatifitas dan kedisiplinan serta ekstra kurikuler lainnya. ${ }^{7}$

Jadi apabila suatu sekolah atau lembaga pendidikan telah melaksanakan hal-hal tersebut diatas atau sedang menuju kearah pembelajaran dan manajemen tersebut maka dapat diklasifikasikan sebagai sekolah unggulan.

\section{Penyusunan Kurikulum sekolah Unggulan}

Kurikulum pada dasarnya adalah seperangkat perencanaan dan media untuk mengantarkan lembaga pendidikan dalam mewujudkan tujuan pendidikan yang diinginkan. Kurikulum juga dapat diartikan menurut fungsinya sebagaimana dalam pengertian berikut :

a) Kurikulum sebagai program studi, maka kurikulum di defenisikan sebagai seperangkat mata pelajaran yang mampu dipelajari oleh peserta didik .

b) Kurikulum merupakan kegiatan yang direncanakan tentang hal yang akan diajarkan untuk memcapai suatu keberhasilan.

c) Kurikulum sebagai hasil belajar, yaitu seperangkat hasil belajar yang direncanakan dan diinginkan.$^{8}$

Oleh karena itu kurikulum sekolah unggulan dirancang berdasarkan pertimbangan-pertimbangan yang menjadi tujuan, pengembangan konsep dan kaidah-kaidah dasar pelaksanaan proses belajar mengajar, sehingga kurikulum yang diaplikasikan pada sekolah unggulan adalah kurikulum yang tidak hanya memperhatikan integrasi

7 Muhammad Ansyar, Dasar-dasar Pengembangan Kurikulum (Jakarta: Depdikbud, 1989 ), 8-10

${ }^{8}$ Tim Penyusun, Sistem Penyelenggaraan sekolah Unggul ( Jakarta, Depdikbud RI, 1993) 
anatara pengembangan logika, etika, estetika, tetapi juga kemampuan berfikir holistik, kreatif dan sistematik serta kondisi dan spesifik daerah. Penjelasan ini mempertegas bahwa penyusunan kurikulum sekolah atau madrasah unggulan selalu melibatkan pendekatan teknologi sehingga berbeda dengan sekolah lainnya. Sebagai contoh adalah kurikulum yang diterapkan pada pendidikan di SMA Dwiwarna Parung Bogor selain mengacu pada pedoman yang ditetapkan oleh Diknas, juga menggunakan program pengembangan yang meliputi bidang keagamaan, minat dan bakat serta bidang-bidang sosial dan kebudayaan.

1. Pengembangan wawasan keagamaan.

Sistem pengembangan wawasn keagamaan dilakukan dengan jalan : Pedoman kegiatan ibadah dan keagamaan, Kegiatan ibadah harian, Pendidikan Akhlaqul Karimah, Membaca dan menulis Al-Qur'an, Studi naskah kitab kuning, Pengenalan dasar bahasa Al-qur'an dan Ceramah umum.

Pengelolaan kegiatan pengembangan wawasan keagamaan sebagaimana disebut diatas merupakan suatu teknologi yang dikembangkan oleh sekolah unggulan yang berciri khas islami. Dimana telah dirancang sebagaimana mestinya sesuai dengan visi dan misi lembaganya.

2. Pengembangan pendidikan bakat siswa.

Siswa yang tergolong berkecerdasan dan berkemampuan luar biasa (berbakat) berhak memperoleh pendidikan khusus menurut UU Sisdiknas No. 2 tahun 1989. Siswa yang memiliki bakat yang sama ditempatkan dalam satu kelompok untuk melakukan eksplorasi secara bersamaan. Pengembangan bakat ini adalah sesuai dengan konsep 
intelegensi Howard Gardner, yaitu Theory of Multiple Intellegences yang meliputi tujuh kompetensi yakni ; linguistik, logika-matematika, sosial, kinestetik, musik, inter-pribadi dan intra-pribadi.

3. Pengembangan pendidikan dan soaial kemasyarakatan yaitu Kepemimpinan, Pembinaan seni budaya, jurnalistik,Pengembangan komunikasi berbahasa Inggris. ${ }^{9}$

Pengembangan pendidikan dan sosial kemasyarakatan ini dituangkan guna memenuhi kebutuhan siswa setelah keluar dari sekolah tersebut hendaknya telah mempunyai program yang jelas dan dapat mengaplikasikan ilmunya di luar. Sehingga dalam era globalisasi ini dapat tetap stabil dalam kehidupannya sesuai dengan ilmu yang telah diperoleh.

\section{Manajemen Sekolah Unggulan}

Secara umum, manajemen berbasis sekolah (MBS) merupakan model manajemen yang memberikan otonomi lebih besar kepada sekolah dan mendorong pengambilan keputusan partisipatif yang melibatkan secara langsung semua warga sekolah untuk meningkatkan mutu sekolah berdasarkan kebijakan nasional ${ }^{10}$. Dengan otonomi yang lebih besar, maka sekolah akan memiliki kewenangan yang lebih besar dalam mengelola sekolahnya, sehingga sekolah lebih mandiri.

${ }^{9}$ Kemenag RI, Pola Pengembangan sekolah berasrama, study kasus SMA Dwiwarna (Jakarta, $2001), 9$

10 Budi Rahardjo, Manajemen Berbasis Sekolah, (Jakarta,Dirjen Dikdasmen, 2004 ), 3 
Adapun tujuan ditetapkannya MBS secara umum adalah :

a) Meningkatkan mutu pendidikan melalui kemandirian dan inisiatif sekolah dalam mengelola dan memberdayakan sumber daya yang tersedia.

b) Meningkatkan kepedulian warga sekolah dan masyarakat dalam menyelenggarakan pendidikan melalui pengembilan keputusan bersama.

c) Meningkatkan tangggung jawab sekolah kepada orang tua, masyarakat dan pemerintah tentang mutu sekolahnya.

d) Meningkatkan kompetisi yang sehat antar sekolah tentang mutu pendidikan yang akan dicapai 11

MBS mempunyai karakteristik yang perlu dipahami oleh warga aekolah yang akan menerapakannya. Dengan kata lain apabila sekolah tersebut ingin sukses dalam menerapkan MBS, maka sejumlah karakteristik tersebut harus dimiliki. Adapun karakteristik itu adalah sebagai berikut :

1. Out put yang diharapkan

Out put adalah prestasi sekolah yang dihasilkan oleh proses pembelajaran dan manajemen sekolah. Out put diklasifikasikan menjadi dua macam, yaitu : Prestasi akademik dan non akademik.

11 Budi Rahardjo, 5

Bidayatuna | p-ISSN: 2621-2153, e-ISSN: 0000-0000 | 27 
2. Proses

Sekolah yang efektif memiliki kualitas proses pendidikan sebagai berikut :

a. Proses belajar mengajar yang efektif

b. Kepemimpinan sekolah yang kuat

c. Lingkungan sekolah yang aman dan tertib

d. Pengelolaan tenaga kependidikan yang efektif

e. Memiliki budaya mutu

f. Memiliki team work yang kuat

g. Memiliki kewenangan

h. Partisipasi yang tinggi dari warga sekolah

i. Memiliki keterbukaan

j. Memiliki kemauan untuk berubah

k. Responsif dan antisiapasif terhadap kebutuhan

1. Melakukan evaluasi dan perbaikan secara berkelanjutan

m. Komunikasi yang baik

n. Memiliki akuntabilitas

3. Input Pendidikan 
Dalam kontek MBS input pendidikan diartikan secara luas, meliputi :
a. Memiliki kebijakan, tujuan dan sasaran mutu yang jelas
b. Sumber daya tersedia dan siap
c. Staf yang kompeten dan berdedikasi tinggi
d. Memiliki harapan dan prestasi yang tinggi
e. Fokus pada pelanggan (Stake holder)
f. Input manajemen ${ }^{12}$

Penekanan keefektifan sekolah adalah proses belajar yang berlangsung secara aktif atau ada keterlibatan berbagai pihak terutama siswa dan guru sebagai subjek belajar. Namun demikian sebagai lembaga, sekolah tidak hanya menghadapi siswa tetapi sumber daya lain yang patut diperhatikan kebutuhannya, harapannya dan aspirasinya. Pemikiran bahwa siswa adalah segala-galanya pantas untuk dikembangkan, Tetapi dalam praktek manajemen tidak terlepas dari komponen -komponen yang membuat siswa menjadi segala-galanya. Kurikulum yang terorganisir merupakan indikator sekolah efektif. Keadaan kurikulum tidak hanya dilihat dari hasil belajar siswa, tetapi proses ke arah itu yang ditandai dengan analisis kurikulum untuk setiap mata pelajaran, penyusunan silabus, pembuatan lembar kerja siswa (LKS) dan berbagai program perangkat kurikulum yang dimaksudkan sebagai penyediaan layanan pembelajaran terbaik bagi siswa. ${ }^{13}$

\footnotetext{
12 Budi Rahardjo, 44

${ }^{13}$ Komariyah, Visionary Leadership menuju Sekolah Efektif, ( Jakarta:Bumi Aksara, 2005 ),46
} 
Banyak sekali pendekatan teknologis yang dipakai dalam memanej penyelenggaraan sekolah unggulan, sehingga disana akan tampak berbagai macam keunggulan dan kemampuan yang dimiliki siswa, serta sekolah tersebut dapat bersaing dan berkompetisi dengan cara yang wajar tanpa ada perseteruan antara sekolah yang satu dengan yang lainnya. Karena sesungguhnya yang ingin dicapai oleh sekolah unggulan adalah keunggulan dalam bidang ilmu pengetahuan dan teknologi serta kompetensi sosial yang paralel dengan kemulian akhlaqnya, dengan kata lain unggul secara utuh.

\section{Permasalahan dan Alternatif Solusi}

Bila boleh mengkritisi, pelaksanaan sekolah unggulan di Indonesia memiliki banyak kelemahan, antara lain, pertama, sekolah unggulan disini membutuhkan legitimasi dari pemerintah bukan atas inisiatif masyarakat atau pengakuan masyarakat. Sehingga penetapan sekolah unggulan cenderung bermuatan politis dari pada muatan edukatifnya. Apabila sekolah unggulan didasari atas pengakuan masyarakat maka pemerintah tidak perlu mengucurkan dana lebih kepada sekolah unggulan, karena masyarakat akan menangggung semua biaya atas keunggulan sekolah itu. Kedua, Sekolah unggulan hanya melayani golongan kaya, sementara itu golongan miskin tidak mungkin mampu mengikuti sekolah unggulan walaupun secara akademis memenuhi syarat. Untuk mengikuti kelas unggulan, selain harus memiliki kemampuan akademis tinggi juga harus meyediakan uang jutaan rupiah. Artinya penyelenggaraan sekolah unggulan bertentangan dengan prinsip equity, yaitu terbukanya akses dan kesempatan yang sama bagi setiap orang untuk menikmati pendidikan yang baik. Keadilan dalam penyelenggaraan pendidikan ini amat penting agar kelak melahirkan manusia-manusia unggul yang memiliki hati nurani yang berkeadilan. 
Ketiga, Profil sekolah unggulan kita hanya dilihat dari karakteristik prestasi yang tinggi berupa NEM, input siswa yang memiliki NEM tinggi, ketenagaan berkualitas, sarana dan prasarana yang lengkap, dana sekolah yang besar kegiatan belajar mengajar dan pengelolaan sekolah yang kesemuanya sudah unggul. Wajar saja bila bahan masukannya bagus, diproses di tempat yang baik dan dengan cara yang baik pula maka keluarannya otomatis bagus. Yang seharusnya disebut unggul adalah apabila masukan biasa biasa saja atau kurang baik tetapi di proses di tempat yang baik dengan cara yang baik pula sehingga out putnya juga bagus.

Oleh karena itu penyelenggaraan sekolah unggulan harus segera direstrukturisasi agar benar-benar bisa melahirkan manusia unggul yang bermanfaat bagi negeri ini. Bibit-bibit manusia unggul di Indonesia cukup besar, karena parivelensi anak berbakat sekitar 2\% artinya setiap 1000 orang terdapat 20 anak berbakat. ${ }^{14}$ Jadi jika penduduk usia sekolah di Indonesia ada 100.000.000, maka kita akan memiliki 2.000.000 anak yang unggul atau berbakat.

\section{Restrukturisasi Sekolah unggulan}

Konsep sekolah ungggulan yang tidak unggul ini harus segera di restrukturisasi. Restrukturisasi sekolah unggulan yang ditawarkan adalah sebagai berikut: Pertama, Program sekolah unggulan tidak perlu memisahkan antara anak yang memiliki bakat keunggulan dengan anak yang tidak memiiki bakat keunggulan. Kelas harus dibuat heterogen sehingga anak yang memiliki bakat bisa bergaul dan bersosialisi dengan

\footnotetext{
14 Daniel P Hallahan dan James M.Kauffman, Exceptional Children : Introduction To Special Education, (New Jersey:Prentice-Hall International, Inc, 1991), 6-7
}

Bidayatuna | p-ISSN: 2621-2153, e-ISSN: 0000-0000 | 31 
semua orang dari tingkatan dan latar belakang yang beraneka ragam. Pelaksanaan pembelajaran harus menyatu dengan kelas biasa, hanya saja siswa yang memiliki bakat keunggulan tertentu disalurkan dan dikembangkan bersama-sama dengan anak yang memiliki bakat keunggulan serupa, misalnya anak yang memiliki bakat keunggulan seni tetap masuk dalam kelas reguler, namun diberi pengayaan pelajaran seni.

Kedua, Dasar pemilihan keunggulan tidak hanya didasarkan pada kemampuan intelegency (kecerdasan) dalam lingkup sempit yang berupa kemampuan logika-matematika seperti yang diwujudkan dalam tes IQ. Keunggulan seseorang dapat di jaring melalui berbagai bakat yang dimiliki siswa.

Ketiga, Sekolah unggulan jangan hanya menjaring anak yang kaya saja, tetapi menjaring semua anak yang memiliki bakat keunggulan dari semua kalangan dengan beaya subsidi silang. Berbagai sekolah unggulan yang dikembangkan di Amerika justru untuk membela kalangan miskin, misalnya Efectif scholl yang dikembangkan awal 1980-an oleh Ronald Etmon dari Harvard Univercity adalah untuk membela anak dari kalangan miskin karena prestasinya tak kalah dengan anak kaya. Demikian pula dengan school development program yang dikembangkan oleh James Comer ditujukan untuk meningkatkan pendidikan bagisiswa yang berasal dari keluarga miskin. Accelerated school yang diciptakan oleh Hendry Levin dari Standford Univercity juga memfokuskan untuk memacu prestasi yang tinggi pada siswa kurang beruntung. Essential scholl yang diciptakan oleh Theodore Sizer dari Brown Uniovercity, ditujukan untuk memenuhi kebutuhan siswa kurang mampu. 
Keempat, sekolah unggulan harus memiliki model manajemen sekolah yang unggul yaitu yang melibatkan partisipasi semua stake holder sekolah, memiliki kepemimpinan yang kuat, memiliki budaya sekolah yang kuat, mengutamakan pelayanan pada siswa, menghargai prestasi setiap siswa berdasar kondisinya masing-masing, terpenuhinya harapan siswa dan berbagai pihak terkait dengan memuaskan. Itu semua akan tercapai apabila pengelolaan sekolah telah mandiri diatas pundak sekolah sendiri,bukan ditentukan oleh birokrasi yang lebih tinggi.

Jadi. sekolah unggulan yang bertujuan menyiapkan masa depan bangsa agar siap menghadapi kehidupan yang kompetitif, maka sekolah harus menyiapkan semua perangkatnya input - proses - akhirnya out put (juga) unggul, kreatif, inovatif tanpa adanya diskriminasi antara siswa kaya dengan miskin, berbakat dengan tidak berbakat, karena pendidikan itu untuk hak semua manusia (Education for all). Semuanya berhak mendapat pendidikan terbaik bukan orang miskin dilarang sekolah, yang berarti dilarang pintar.

\section{Kesimpulan}

Dari pemaparan yang sangat singkat dapat diambil suatu kesimpulan bahwa sekolah Unggulan agar dapat telaksana dengan baik hendaknya melibatkan berbagai komponen yang sangat menunjang dan saling mendukung. Diantara komponen tersebut tentunya harus dapat berjalan dengan seksama dan mempunyai visi dan misi yang sama pula sehingga nantinya tidak akan terjadi suatu kesenjangan dalam menjalankannya.

Dengan komponen tersebut, jika dapat dipenuhi secara maksimal, maka sekolah unggulan yang diharapakan akan terwujud yang pada akhirnya 
out put yang dihasilkan lebih baik dan lebih siap sehingga dapat bersaing dalam percaturan dunia global.

\section{Daftar Pustaka}

Budi Rahardjo, 2004. Manajemen Berbasis Sekolah, Jakarta:Dirjen Dikdasmen.

Daniel P Hallahan dan James M.Kauffman, 1991. Exceptional Children : Introduction To Special Education, New Jersey: Prentice-Hall International,Inc,

Depag RI, 2001. Pola Pengembangan sekolah berasrama, study kasus SMA Dwiwarna, Jakarta:Depag RI

E. Mulyasa, 2003. Kurikulum Berbasis Kompetensi (Bandung,Remaja Rosdakarya,

H.A.R Tilaar, 1999. Beberapa agenda Reformasi Pendidikan Nasional dalam Persepektif Abad 21, Jakarta, Indonesia: Tera, (Http : // artikel.us/nurkolis3)

Komariyah, 2005. Visionary Leadership menuju Sekolah Efektif, Jakarta: Bumi Aksara

Muhammad Ansyar, 1989. Dasar-dasar Pengembangan Kurikulum (Jakarta, Depdikbud)

Nanang Fatah, 2000. Manajemen Berbasis Sekolah , Bandung: Andira, 2000.

Susan Alberts Mohrman, dkk., School Based Management : Organizing for Hight Performance, San Fransisco,

Tim Penyusun, 1994. Sistem Penyelenggaraan sekolah Unggul, Jakarta: Depdikbud RI, 1993.

T. Cholik Mutohir, 1997. Wawasan Keunggulan dalam Konteks Pengembangan Sekolah Unggulan, Surabaya:IKIP. 